Table 1. Measurements of Euphalangium martensi sp. nov. legs I - IV (in $\mathrm{mm}$ )

\begin{tabular}{llllllll}
\hline Male & \multicolumn{2}{l}{ Trochanter Femur } & Patella & Tibia & Mt-tarsus & Tarsus & Total \\
\hline Leg I & 0.6 & 4.3 & 1.2 & 4.0 & 4.0 & 7.4 & 21.5 \\
Leg II & 0.6 & 9.1 & 1.5 & 7.3 & 2.8 & 20.0 & 41.3 \\
Leg III & 0.6 & 3.5 & 0.9 & 3.8 & 4.8 & 6.0 & 19.6 \\
Leg IV & 0.6 & 5.0 & 0.9 & 5.0 & 5.7 & 10.2 & 27.4 \\
& & & & & & & \\
\hline Female & \multirow{2}{*}{ Trochanter } & Femur & Patella & Tibia & Mt-tarsus & Tarsus & Total \\
\hline \multirow{2}{*}{ Leg I } & 0.6 & 3.1 & 1.1 & 3.0 & 2.7 & 5.5 & 16.0 \\
Leg II & 0.6 & 5.5 & 1.3 & 5.3 & 2.5 & 16.3 & 31.5 \\
Leg III & 0.6 & 2.7 & 1.0 & 2.8 & 3.2 & 5.7 & 16.0 \\
Leg IV & 0.6 & 4.8 & 1.0 & 3.5 & 2.3 & 8.5 & 20.7 \\
\hline
\end{tabular}

\section{REFERENCES}

Martens, J. (1973). Opiliones aus dem Nepal Himalaya. II Phalangiidae und Sclerosomatidae (Arachnida). Senckenbergiana Biologica 54(1/3): 181-217.
Roewer, F.C. (1911). Uebersicht der genera der subfamilie der Phalangiini de Opiliones Palpatores nebst Beschreibung einiger newer Gattungen und Arten. Arch. Natg. Berlin 77 Bd1 Suppl- H 2: 1-106.

Roewer, F.C. (1912). Revision der Opiliones Palpatore (=Opiliones Plagiostheti) T1. II: Familie der Phalangiidae, (Subfamilien: Sclerosomini, Oligophini, Phalangiini) Hamburg Abh. Natw. Ver. 20 H 1: 1-295.

Suzuki, S (1966). Four phalangids from eastern Himalayas- Japan Journal of Zoology 15(2): 101-104.

\section{ACKnowledgement}

Authors fore mostly thank Dr. R.M. Sharma, Scientist-C and Officer-inCharge, High Altitude Zoolgy Field Station, Zoological Survey of India, Solan, Himachal Pradesh, for sending the phalangid specimens and allowing us to study and also permitting us for dissecting the specimen for genital studies. We are also indebted to Dr. J.R.B. Alfred, Director, Zoological Survey of India, Kolkata and Dr. A.S. Mahabal, Scientist-E and Officer-in-Charge, Zoological Survey of India, Western Regional Station, Pune for providing us the necessary laboratory and library facilities. We are also thankful to Mr. P.W. Garde, Sr. Artist, ZSI, WRS, Pune for preparation of the final diagrams.

\title{
FIRST RECORD OF GENUS CALLIHORMIUS ASHMEAD (HYMENOPTERA: BRACONIDAE) FROM INDIA, WITH DESCRIPTION OF A NEW SPECIES
}

\author{
S.M. Kurhade
}

Department of Zoology, New Arts, Commerce and Science College, Ahmednagar, Maharashtra 414001, India Corresponding Address: 'Riddhisiddhi', Vidya Colony, Opp. HUDCO, Pipeline Road, Ahmednagar, Maharashtra 414003, India

\begin{abstract}
A new hymenopteran of the family Braconidae, Callihormius orientalis sp. nov. has been described and illustrated. This represents the first record of this genus from India in IndoAustralian region.

\section{KEYWORDS}

Braconidae, Callihormius orientalis sp. nov., Hymenoptera, new description, new record
\end{abstract}

Ashmead (1900) erected the genus Callihormius with Pambolus bifasciatus Ashmead as its type species. Marsh (1966) revised this genus. This is a very small genus with only seven species described from Nearctic and Neotropical regions (Shenefelt \& Marsh, 1976).

In the present work Callihormius is recorded for the first time from India in Indo-Australian region. The key to the Nearctic species of Callihormius by Marsh (1966) has been followed and the new species is compared with Callihormius bajaensis Marsh (1966).

Types of this species are presently retained in the Entomological collection of Dr. Babasaheb Ambedkar Marathwada University, Aurangabad.

\section{Callihormius orientalis sp. nov.}

(Figs. 1-4)

Holotype: Female, 14.xi.1990, Ahmednagar, Maharashtra, India. On wing, coll. S.M. Kurhade, BAMU-SMK-101. Antenna, wings and legs mounted on slides and labelled as above.

Paratypes: 6 females, 14.xi.1990, Ahmednagar, Maharashtra, India. On wing, coll. S.M. Kurhade, BAMU-SMK-102-107.

\section{Etymology}

The species name is derived from the name of the region of its occurrence.

\section{Diagnosis}

Female: 3.8mm. (Fig. 1). Head (Fig. 2) 0.9 times as long as wide; vertex coriaceous, with few shallow punctures; ocellar region not raised, coriaceous; inter-ocellar distance 0.7 times the ocelloocular distance; frons coriaceous, concave; face convex, closely punctate, pubescent, 0.55 times as long as wide; clypeus small, triangular, 0.4 times as long as wide, punctate, pubescent; malar space $1.75 \mathrm{x}$ as long as basal width of mandible, coriaceous and punctate; mandible bidentate, stout, $1.75 \mathrm{x}$ as long as wide, with bristles; temple broad, coriaceous, with a few punctures, 0.45 times as wide as height of eye; eye bare, $2.15 \mathrm{x}$ as long as wide; occipital carina distinct. Antenna 2+26 segmented, long, 




Figures 1-4. Callihormius orientalis sp. nov. (Female) 1 - Adult, lateral view; 2 - Head, frontal view; 3 - Proplerum and Petiole; 4 - Fore wing

filiform; scape $1.5 \mathrm{x}$ as long as wide; pedicel as long as wide; penultimate segment $4 \mathrm{x}$ as long as wide; terminal segment $4 \mathrm{x}$ as long as wide.

Thorax: 2x as long as wide; pronotum coriaceous, epomia distinct; mesoscutum coriaceous; notauli absent; prescutellar depression transversely crenulated; secutellum convex, coriaceous; mesopleurum coriaceous,; mesopleural fovea distinct; mesopleural groove extending to the length of mesopleurum; prepectal carina distinct; metapleurum coriaceous; propodeum (Fig. 3) without areola, median longitudinal carinae distinct, lateral area closely punctate, apical area with two longitudinal carinae; propodeal spiracle round; four lateral longitudinal carinae present. Fore wing (Fig. 4) $4.85 \mathrm{x}$ as long as broad; stigma $4.5 \mathrm{x}$ as long as wide; costa $2.5 \mathrm{x}$ as long as stigma; metacarpus as long as stigma; discoidal cell present; first abscissa of radius $1.3 \mathrm{x}$ as long as breadth of stigma; second abscissa of radius $5 \mathrm{x}$ as long as first abscissa; apical abscissa of radius $1.15 \mathrm{x}$ as long as second abscissa and meeting to the wing margin; basal vein 0.8 times as long as the stigma; medius $2.35 \mathrm{x}$ as long as basal vein; nervulus opposite, slightly reclivous; discoideus $1.35 \mathrm{x}$ as long as stigma; subdiscoideus $1.15 \mathrm{x}$ as long as discoideus; submedius as long as medius. Hind wing $5.35 \mathrm{x}$ as long as broad; subcostella $1.35 \mathrm{x}$ as long as one tacarpella; mediella 0.75 times as long as subcostella. Hind coxa $1.5 \mathrm{x}$ as long as wide; trochanter 0.8 times as long as coxa; $1^{\text {st }}$ trochanter $1.25 \mathrm{x}$ as long as wide; second trochanter $1.25 \mathrm{x}$ as long as wide; femur $3.55 \mathrm{x}$ as long as wide and $2 \mathrm{x}$ as long as coxa; tibia $1.4 \mathrm{x}$ as long as femur, tibial spur 0.35 times as long as basitarsus; basitarsus 0.4 times as long as tibia; claw bifid.

Gaster: $2.65 \mathrm{x}$ as long as wide, petiolated, wide in the middle; petiole $5 \mathrm{x}$ as long as basal width, $2.25 \mathrm{x}$ as long as wide apically as basally, closely punctate, pubescent; second tergite as long as basal width, longitudinally striate, closely punctate, pubescent; third tergite 0.4 times as long as basal width, longitudinally striate and closely punctate medially, finely coriaceous laterally; fourth tergite 0.35 times as long as basal width, smooth, coriaceous, pubescent; fifth tergite 0.55 times as long as basal width, smooth, coriaceous, weakly, shallowly punctate, pubescent; ovipositor 0.75 times as long as abdomen; ovipositor sheath as long as ovipositor, pubescent.

Colour: Black. Antennae, tarsomeres (except last), ovipositor redish-brown; stigma, veins blackish-brown; fore wing with blackish-brown bands; hind wing hyaline.

\section{Male: Unknown.}

\section{Comments}

Callihormius orientalis sp. nov. closely resembles the Nearctic species, Callihormius bajaensis Marsh (1966). However, the new species differs from the same in having the following characters: (i) body black (dark brown), (ii) vertex coriaceous, with a few shallow punctures (vertex granular), (iii) frons coriaceous (frons granular), (iv) temple coriaceous (temple smooth), (v) face closely punctate (face rugulose), (vi) scutellum convex, coriaceous (scutellar disc granular, convex), (vii) propodeum without areola, median longitudinal carina distinct, lateral area closely punctate (propodeum without definite carinae, rugose, slopping gradually to apex), (viii) mesopleurum coriaceous (mesopleurum granular), (ix) first tergite closely punctate (first abdominal tergum longitudinally rugose and granular), and (x) tergites 2 and 3 longitudinally striate (tergum $2+3$ longitudinally rugose and granular); hence justifying the description of a new species.

\section{REFERENCES}

Ashmead, W.H. (1900). Classification of the ichneumon flies, or the superfamily Ichneumonoidea. Proceedings of United States National Museum 23: 1-220.

Marsh, P.M. (1966). The Nearctic Doryctinae, III. The genus Callihormius Ashmead (Hymenoptera: Braconidae). Proceedings of Entomological Society of Washington 68(3): 240-246.

Shenefelt, R.D. and P.M. Marsh (1976). Braconidae 9, Doryctinae, Hymenopterorum Catalogus 13: 1263-1424.

\section{ACKNOWLEDGEMENTS}

I am grateful to Prof. P.K. Nikam, former Head, Department of Zoology, Dr. Babasaheb Ambedkar Marathwada University, Aurangabad for his expert guidence. Thanks are also due to the authorities of New Arts, Commerce and Science College, Ahmednagar for their kind permission to carry this work at Dr. Babasaheb Ambedkar Marathwada University Aurangabad (Maharashtra).

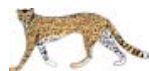

